\title{
Was Freud, At Heart, A Realistic Romantic?
}

Kathleen O'Dwyer

T he birth of psychoanalysis at the close of the nineteenth century coincided with a questioning of philosophical traditions and methods epitomized by Nietzsche's assault on current thinking. The Enlightenment had seen the questioning of religion as an explanation and a revelation of reality and of human life within that reality; science had been instigated as a more 'enlightened' and a more rational provider of truth and knowledge; but the ongoing nature of philosophical thought continued to encounter new challenges and the re-phrasing of old questions. Attempting to combine the exactness of scientific method with the openness of philosophical inquiry, psychoanalysis broached the terrain of the human mind, and attempted to explore the perennial questions of meaning, truth and life with an understanding enhanced by the discoveries of its founder, Sigmund Freud.

The theories of psychoanalysis as developed, outlined, and revised by Freud are the subject of debate in almost every area of the human sciences, and continue to provoke praise and criticism, adulation and disdain, interpretation and re-interpretation, to the present day. In his writings, Freud often acknowledged the possibility of fallibility; he prefaced many of his remarks as being his own speculations, 'I therefore dare not set myself up as a prophet visa-vis my fellow men' ${ }^{1}$ and he expressed the hope that what he had merely initiated would profit from the thought and experience of future reflection and insight:

You will not find me inaccessible to your criticism. I know how difficult it is to avoid illusions; perhaps the hopes I have confessed to are of an illusory nature . . . If experience should show . . . that we have been mistaken, we will give up our expectations. ${ }^{2}$

A poetic expression of these sentiments is offered by W.H. Auden in his poem, "In Memory of Sigmund Freud": 'For every day they die / among us, those who were doing us some good, / who knew it was never enough but /

\footnotetext{
${ }^{1}$ Sigmund Freud, Civilization and Its Discontents (London: Penguin Classics, 2002), 81.

2 Sigmund Freud, The Freud Reader, ed. by Peter Gay (New York: W.W. Norton \& Company, 1995), 719.
} 
hoped to improve a little by living. ${ }^{3}$ It is not the purpose of this paper to offer a critique of Freud's thought; the questionable nature of the scientific basis of his pronouncements and techniques, his limited and distorted representation of female sexuality and psychology, and the prejudices and limitations inherent in his historical and geographical position, are subjects explored competently and comprehensively by many writers; ${ }^{4}$ the focus here is on a reading of Freud from the point of view of his contribution to our understanding of human nature, the limits to that understanding, and the obstacles which stand in the way of understanding, happiness and love within the experience of the human condition. This is the view of Jonathan Lear as he outlines Freud's legacy: 'He listened to ordinary people, and, on the basis of what he heard, he transformed our conception of the human. ${ }^{5}$ This contribution is summarized with hope and humility in the closing words of Freud's short essay, "An Autobiographical Study", where he reflects:

Looking back, then, over the patchwork of my life's labours, I can say that I have made many beginnings and thrown out many suggestions. Something will come of them in the future, though I cannot myself tell whether it will be much or little. I can, however, express a hope that I have opened up a pathway for an important advance in our knowledge. ${ }^{6}$

The 'pathway' which Freud 'opened up' evolved from his theories of the unconscious, the structure of the mind, the influences of past experiences, and the interpretation of dreams as 'the via regia to a knowledge of the unconscious element in our psychic life."7 It has led to an acknowledgement of the indeterminacy of knowledge, especially self-knowledge, an awareness of unconscious forces motivating and directing human behaviour, and an attempt to understand and alleviate human distress through an innovative approach to language and interpretation.

The development of psychoanalysis centred on the relationship between two human beings, the analyst and the analysand, and within this relationship the neurosis, sufferings and conflicts of the individual were explored through expression/narration, interpretation/hermeneutics, and understanding/integration. The revolutionary nature of this approach lay in the proposition that human suffering could be understood and alleviated by the

3 W.H. Auden, Collected Poems (London: Faber and Faber, 1994), 273.

${ }^{4}$ Walter Kaufmann, Jonathan Lear and Adam Phillips provide commentaries on the issues which are sympathetic to Freud's position; Philip Rieff is less enthusiastic in his appraisal and sees in Freud's thought a conservative moralism; Richard Webster finds much to condemn and ridicule in his reading of Freud. Carol Gilligan, among other feminists, offers a feminist critique of Freud's work and the gender bias underlying psychoanalysis in general.

${ }^{5}$ Jonathan Lear, Freud (New York: Routledge, 2005), 9.

${ }^{6}$ Freud, The Freud Reader, 41.

7 Sigmund Freud, The Interpretation of Dreams (Herfordshire: Wordsworth Editions Limited, 1997), 441. 


\section{REALISTIC ROMANTIC}

presence of an understanding, listening and attentive other, rather than through the diagnosis-prescription model. The enriching power of dialogue, the cathartic liberation of narrating one's life-story, and the potential for healing in an encounter with a non- judgemental, accepting and interpretive reflection of an other, not only heralded a radical innovation in the treatment of mental diseases but also suggested a new framework for an understanding of the human condition, and particularly the sourcing of that understanding in the realm of language. In his analysis of Freud's influence, Adam Phillips emphasises the role of language as the medium of psychoanalysis. He suggests that the work of listening and talking in a psychotherapeutic encounter aims at a re-description of the individual's life story, a re-interpretation of what he finds unacceptable or unbearable, in such a way that it becomes tolerable, sensible, and hopefully pleasurable; 'that suffering can sometimes be transformed by applying words to wounds . . . the appeal to another person to listen and reply is fraught with hope.' 8 The goal of psychoanalysis for Freud was the amelioration of mental suffering, the release of the individual from unnecessary psychic conflict and constraint, and the liberation of the human subject to live, work and love in the world. He believed that bringing to consciousness the memories, desires, unfulfilled wishes and forgotten traumas which had been repressed, enabled the subject to attain a more realistic and a more honest understanding of motivation, feeling and behaviour, and ultimately empowered the individual to make an autonomous decision regarding a response to this increase in self-knowledge. The psychoanalytic aim was 'to uncover repressions and replace them by acts of judgement which might result either in the accepting or in the condemning of what had formerly been repudiated.' ${ }^{\prime}$ However, these goals could only be pursued through selfhonesty, self-acceptance, and self-integration. Thus, Freud's psychoanalysis inevitably examines the obstacles to such an achievement, and contributes to an exploration of the potential obstacles to human happiness.

\section{The Unconscious}

The decisive rules of logic don't apply in the unconscious; we could call it the Empire of the Illogical. ${ }^{10}$

Freud's development of psychoanalysis centres on his close observation of human behaviour including an on-going analysis of his own psyche, dreams and motivations. This observation led to a growing conviction that in many life situations unconscious influences impact on human thought, feeling and action, and from this insight Freud discerns many of the obstacles to health, happiness and optimum living. Misconceptions, disavowals and

\footnotetext{
8 Adams Phillips, Side Effects (London: Penguin Books, 2006), 19.

${ }^{9}$ Freud, The Freud Reader, 18.

10 Sigmund Freud, The Penguin Freud Reader, ed. by Adam Phillips (London: Penguin,
} 2006), 23. 
transferred feelings from one situation to another diminish the possibility of genuine relationship, with self and other, and according to Freud, distort and thwart the possibility of happiness. Exploration of the unconscious, the retrieval of repressed material, and the assumption of personal responsibility, would, according to Freud's theories, enhance self-knowledge and selfacceptance, and free the subject to make life-enhancing choices unrestricted by developmental arrest or traumatic fixation. ${ }^{11}$

Through his studies, writings, clinical practice and self-analysis, Freud developed a new and broader picture of psychic life than had hitherto been considered. Examining the symptoms of malaise and unhappiness, Freud discerned that one's conscious awareness of oneself is only one part of the mind's structure; 'mental processes are in themselves unconscious and . . . of all mental life it is only certain individual acts and portions that are conscious.' ${ }^{12}$ The original inspiration for the term was literary, as Lacan reminds us: 'Freud called the locus of the unconscious ein anderer Schauplat;, another scene, borrowing a term that had struck him in a text by Fechner.'13 Hence, Freud developed a model of the mind which would take account of the existence of the unconscious. His model breaks with the Cartesian cogito with its emphasis on direct introspection and transparency, and rational thought as the guarantor of ontology, and it overturns the pretension of consciousness to truth and meaning as an illusion masking its propensity to be inadequate, capable of mistakes and self-deception. Freud asserts that behind one's conscious awareness of oneself lurks a powerful influence on one's behaviour and health. This part of the mind's structure Freud terms 'the unconscious,' suggesting that what is conscious to the self is but a mere layer of awareness, and that the greater part of mental life lies hidden in this unconscious state: 'Psychoanalysis . . . defines what is mental as processes such as feeling, thinking and willing, and it is obliged to maintain that there is unconscious thinking and unapprehended willing. ${ }^{14}$ The reality of the unconscious, and its role in psychic life, demands a recognition of what the individual tries to hide from himself or herself. Repressed in the unconscious are the hidden, unacknowledged conflicts of the individual, disguised truths and buried memories that strive to be revealed.

Freud believed that human behaviour is determined unconsciously by these primitive drives and impulses, but without our awareness of their

11 Jean-Paul Sartre, Being and Nothingness (London: Routledge, 2003), 70-94.

The positing of the unconscious as a propellant of human behaviour and motivation is rejected by Sartre's critique of Freudian psychoanalysis; he develops the concept of 'bad faith' to account for the phenomenon of self-deception. (Sartre's argument is outlined in his philosophical work Being and Nothingness, and is also explored in novelistic form in works such as Nausea and The Reprieve) However, his assertion that choice is an inescapable component of human living may cohere with Freud's commitment to creating conditions favourable to informed and open decisions and choices freed from the limitations of disavowal and repression. 46.

12 Sigmund Freud, Introductory Lectures on Psychoanalysis (London: Penguin Books, 1991),

${ }^{13}$ Jacques Lacan, Ecrits: A Selection (London: W.W. Norton \& Company, 2004), 183.

${ }^{14}$ Freud, Introductory Lectures on Psychoanalysis, 46. 


\section{REALISTIC ROMANTIC}

influence. According to Lear, 'this goes to the heart of Freud's insight: that humans tend toward certain forms of motivated irrationality of which they have little or no awareness.' ${ }^{15}$ Human suffering can be understood and alleviated only through a recognition of hidden and denied wishes, frustrations, and desires: 'Interpreting means finding a hidden sense in something.' ${ }^{16}$ This definition of interpretation later led to Freud being described, along with Nietzsche and Marx, as one of 'the masters of suspicion.' In his Essay on Interpretation: Freud and Philosophy, Ricoeur differentiates between interpretation as restoration of meaning and the hermeneutics of suspicion as exemplified by psychoanalysis: 'Psychoanalysis . . . has uncovered a variety of processes of elaboration that are operative between the apparent and the latent meaning' and he describes this hermeneutics as 'a tearing off of masks, and interpretation that reduces disguises. ${ }^{17}$ Among the masks to be uncovered through the insights of psychoanalysis is the mask of self-deception and its illusion of self-knowledge. Freud understood the popular opposition to this analysis, and he likened it to the difficulty in accepting the historical blows to naive vanity produced by the discoveries of Copernicus and Darwin. Lacan explains that by comparing his discovery to 'the so-called Copernican revolution' Freud was 'emphasizing that what was at stake was once again the place man assigns himself at the centre of a universe. ${ }^{18}$ With the insights of psychoanalysis, the centrality of the human subject was again questioned.

But human megalomania will have suffered its third and most wounding blow from the psychological research of the present time which seeks to prove to the ego that it is not even master in its own house, but must content itself with scanty information of what is going on unconsciously in its mind. ${ }^{19}$

The assertion that the ego is 'not even master in its own house' infers that it lacks a full awareness of its motivations and expectations, that it is curtailed and directed by unconscious desires and fears, and that its claim to self-knowledge is illusory and mistaken. This difficulty in accepting the limitations of human knowledge, and the simultaneous challenge to our illusory and distorted view of human nature, lie, according to Freud, at the root of human suffering and unhappiness, and he urges a more honest appraisal of human nature which takes cognizance of its contradictions and conflicts. This involves an acceptance of the ambiguity pervading much of human emotion and thought, and the ambiguity underlying the motivation of human behaviour.

Freud presents us with case histories in order to highlight the obstacles to love and happiness which arise when desire and motivation are

\footnotetext{
15 Jonathan, Lear, Lear (London: Routledge, 2005), 4.

${ }^{16}$ Freud, Introductory Lectures on Psychoanalysis, 115.

17 Paul Ricoeur, Frend and Philosophy (New Haven: Yale University Press, 1970), 17, 30.

${ }^{18}$ Lacan, Ecrits, 156.

${ }^{19}$ Freud, Introductory Lectures on Psychoanalysis, 326.
} 
camouflaged; idealization of the love-object, rescue-fantasies, the search for parent-surrogates, and the prohibition of sexual activity under certain conditions, all point to a reluctance to acknowledge the complexity of human experience. In the words of Auden, 'Nothing can be loved too much, / but all things can be loved / in the wrong way. ${ }^{20}$ Rejecting the validity of the Christian dictum of neighbourly love, Freud points to various historical manifestations of its incongruence: 'After St Paul had made universal brotherly love the foundation of his Christian community, the extreme intolerance of Christianity towards those left outside it was an inevitable consequence.'21 Freud's argument against this dictum resounds with Buber's avowal that one cannot love everyone one meets, ${ }^{22}$ and stresses the concrete and practical nature of love over universal theories: 'My love is something I value and must not throw away irresponsibly. It imposes duties on me, and in performing these duties I must be prepared to make sacrifices. ${ }^{23}$

The case histories outlined and analyzed in Freud's texts are instructive, because, he asserts, they illustrate the contradictions inherent in all human behaviour; 'we who laugh at other people's failings are not always free from them ourselves,' ${ }^{24}$ and he concludes from his analyses that the mystery of love eludes systematization and tidy formulae; 'things that have to do with love are incommensurable with everything else; they are, as it were, written on a special page on which no other writing is tolerated. ${ }^{25}$ Freud asserts the discrepancy between love and 'normality stating that 'departures from the norm constitute precisely what is essential about being in love. ${ }^{26}$

\section{Psychic Conflict}

It is a conflict, then, between what the drive demands and what reality forbids. ${ }^{27}$

20 Auden, Collected Poems, 885.

${ }^{21}$ Freud, Civilization and Its Discontents, 51.

22 Martin Buber, Between Man and Man (New York: Routledge Classics, 2004), 24. Buber situates the event of dialogue, of genuine meeting, in the particular, concrete experiences of daily life, rather than in the high moral ground of generalized platitudes and easy clichés: 'The life of dialogue is not one in which you have much to do with men, but one in which you really have to do with those with whom you have to do.' This concentration on the particular and the concrete, on the demands and responsibilities of the face-to-face encounter with actual lived experience in the present moment, is central to the possibility of love, according to Buber, and his assertion that, 'I know no one in any time who has succeeded in loving every man he met,' resounds with the opposition of Nietzsche, Freud, Lacan and Žižek to the dictum of universal love.

${ }^{23}$ Freud, Civilization and Its Discontents, 46.

${ }^{24}$ In light of Freud's persistent atheism, it is interesting to note in this quote the echo of the biblical story of the prostitute and the words 'He who is without sin among you, let him cast the first stone at her' (John 8:7).

${ }^{25}$ Freud, The Freud Reader, 379.

${ }^{26}$ Ibid., 385.

${ }^{27}$ Freud, The Penguin Frend Reader, 64. 


\section{REALISTIC ROMANTIC}

The ambivalence of love is perhaps relative to its essentially subjective character which militates against theoretical formulations and definitions, and which suggests some explanation regarding the diverse interpretations and explorations of the concept. As a subjective experience, whether loving or being loved, it is susceptible to the often conflicting and contradictory demands and needs of the individual, whereby juxtapositions such as desire and duty, fear and fortitude, self-preservation and self-giving, and the myriad manifestations of the complexity of the human condition, jostle with each other towards the attainment of satisfaction. The ensuing conflicts of psychic life seek resolution in diverse forms and behaviours, including disavowal of 'unacceptable' sources of motivation, projection of 'negative' aspects of human nature onto convenient containers, or, in line with psychoanalytic aims, the attempted integration of the full spectrum of instinctual, emotional and mental experience.

Freud's study of the phenomenon of the unconscious led him to conclude that it contained no sort of unity or organisation, but rather uncoordinated impulses seeking satisfaction, often in opposition with each other. Freud understood the mind as potentially in conflict with itself, and he understood this conflict as the primary cause of human anxiety and unhappiness. According to Richard Boothby,

the genuine Freudian insight places the most important site of conflict not between our wishes and the world that limits their fulfillment, but between our wishes and ourselves. The problem is not that we are prevented by reality from fulfilling our desire but that we are prevented from knowing that desire in the first place. ${ }^{28}$

Freud put forward a tripartite division of the mind, whereby different mental functions operate at different levels. His description of three conflicting or competing internal tendencies, the id, ego, and superego, which are not physical structures, but rather aspects and elements of a theoretical model, helps to explain the link between early childhood experiences and the mature adult personality. Here, Freud points to the inherent wisdom of poetic vision, stating that: 'What poets and students of human nature had always asserted turned out to be true: the impressions of that early period of life, though they were for the most part buried in amnesia, left in-eradicable traces upon the individual's growth. ${ }^{29}$ Thus, he encourages a re-visiting of the past, 'he merely told / the unhappy Present to recite the Past / like a poetry lesson,' with a view to enabling a more hopeful and a more autonomous encounter with the future, 'to approach the Future as a friend / without a wardrobe of excuses, without / a set mask of rectitude. ${ }^{30}$ Freud's reference to poets as

\footnotetext{
${ }^{28}$ Richard Boothby, Freud as Philosopher (New York: Routledge, 2001), 278.

${ }^{29}$ Freud, The Frend Reader, 20.

30 Auden, Collected Poems, 274.
} 
'students of human nature,' and his acknowledgement that his own insights, developed through arduous reflection and observation, are often intuitively and creatively known and felt by artists such as poets, suggests the possibility of foundational links between the disciplines of psychoanalysis and poetry.

According to Freud's description of the tripartite division of the mind, the uncoordinated instinctual trends of psychic life form the id. As a primitive motivational force, the id is ruled by the 'pleasure principle,' demanding satisfaction now, regardless of circumstances and possibly undesirable consequences; it contains everything that is inherited, everything present at birth, everything constitutionally determined.' 31 The desires of the id, to be centre-stage, to be omnipotent, and to be permanently satisfied, are driven by the instincts, which are the innate needs of psychic life. These desires are based on the demand for love, for total union and mergence with 'the beloved,' symbolized by the mother, and for the protection of that love, by the symbolic father. Ambivalence pervades the direction of these desires as the protective role of the father is alternated with his challenging position as the mother's lover and thus as a threatening rival for her affections; love and hate are ambiguously and simultaneously experienced. Hence, there is an ongoing attraction to the mirage of the perfect love and the prototypes which embody it, replicating this state which is later 'forgotten' but never fully abandoned.

In his analysis of the subject, Freud argues against the notion of a tabula rasa, a clean slate upon which the individual freely constructs his/her identity and sketches the outline of his/her life. According to Freud, the infant arrives into a world which is already created, already interpreted, already expectant. The interpreted world and its subsequent expectations and demands are reflected in the familial and societal mores and values which are directly or indirectly imposed on the child, and which continue to potentially shape its understanding of and relation to, itself and the world in which it finds itself.

As the child moves from a narcissist conception of himself or herself as embodying the universe, and comes to a mature realisation of the existence of the 'other,' there is a grudging acceptance of the necessity of objectrelations; this is experienced in the attempted accommodation of solitude and connection, self-preservation and self-giving: 'the two strivings-for individual happiness and for human fellowship-have to contend with each other in every individual. ${ }^{32}$ The reality of social and communal life entails a restriction of instinctual desires and primitive drives: 'Men cannot remain children forever. They must in the end go out into "hostile life". We may call this "education to reality". 33 Hence, there is the emergence of 'the reality principle' which must be accommodated in frequent contradiction to 'the pleasure principle.'

\footnotetext{
31 Sigmund Freud, An Outline of Psychoanalysis (London: Penguin Classics, 2003), 176.

32 Freud, Civilization and Its Discontents, 77.

${ }^{33}$ Freud, The Frend Reader, 717.
} 


\section{REALISTIC ROMANTIC}

The eventual understanding that immediate gratification is usually impossible and often unwise, and that 'a child's desires are incompatible with reality,' 34 comes with the formation of the ego. The ego develops as the child forms an image of itself in relation to its environment; it is the gradual emergence of the persona or social self, the public presentation of the self. The ego mediates between the conflicting internal demands of the id and the demands and constraints of the social world: 'It has the task of self-assertion, and fulfils it with respect to the outside world . . . and with respect to the inner world . . . the id. ${ }^{35}$ In its attempted accommodation to the public and social environment, the ego is governed by the 'reality principle,' and in subordinating the demands of the id, it serves as a 'modifier' of the 'pleasure principle,' as it seeks more realistic and attainable goals. Freud explains:

Thanks to the influence of the ego's self-preservation drive it is displaced by the reality principle, which, without abandoning the aim of ultimately achieving pleasure, none the less demands and procures the postponement of gratification, the rejection of sundry opportunities for such gratification, and the temporary toleration of unpleasure on the long and circuitous road to pleasure. ${ }^{36}$

The child learns that his/her needs are met in proportion to the supply by others, and this learning is inevitably followed by an acknowledgement of the power differentials at work in his/her surroundings. Satisfaction of one's needs is dependent on the good-will of one's carers, and their good-will becomes a prerequisite of desire fulfilment: 'the Freudian child suffers, so to speak, from an intensity of desire and an excess of vulnerability. ${ }^{37}$ The intersubjective context of desire is reiterated by Ricoeur, in his interpretation of Freud; the desire of the self is confronted by the desire of the other:

if desire were not located within an interhuman situation, there would be no such thing as repression, censorship, or wish-fulfillment through fantasies; that the other and others are primarily bearers of prohibitions is simply another way of saying that desire encounters another desire-an opposed desire. ${ }^{38}$

The 'interhuman situation' suggests an interpretation of human-being as essentially intersubjective, with all the possibilities for growth and withdrawal which this entails. The potential for camouflage and subterfuge has been created; the experience, imaginary or real, of total, unconditional,

\footnotetext{
${ }^{34}$ Freud, The Penguin Freud Reader, 147.

${ }^{35}$ Freud, Outline of Psychoanalysis, 176.

${ }^{36}$ Freud, The Penguin Frend Reader, 135.

37 Adam Phillips Equals (New York: Basic Books, 2002), 151.

${ }^{38}$ Ricoeur, op cit., 387.
} 
unlimited love by another person becomes a distant dream of the past or an insatiable thirst in the present. Its possibility seems to recede.

The fulfilment of desire is frustrated by the tensions between what is sought and what is possible. Freud turns to the paradigm of the nuclear family and the mythology of Oedipus to portray these tensions: 'the Oedipus fable should probably be understood as the poetic treatment of what is typical about such relationships. ${ }^{39} \mathrm{He}$ refers to 'the profound and universal validity of the old legends' and tells us that the fate of Oedipus 'moves us only because it might have been our own.' ${ }^{40}$ Lear refers to the cathartic effect of this experience:

It is the essence of Freud's account of the appeal of great literature that we can in some way, dimly, recognize ourselves in it. And yet, it is only because the spectator remains aware of the gulf that separates his own life from that of the dramatic hero that he can enjoy indulging in imaginative identification. It is in this fine balance of sympathy and distance that a catharsis can occur. ${ }^{41}$

The Irish poet, Brendan Kennelly makes a similar point with reference to his 'contemporary versions of three Greek tragedies': 'There's an element of healing present pain when one converses with the mythic world.' 42 The legend enables an acknowledgement, within the safe distance of a fictional/literary container, of our hidden desires and fears. This is a particular function of creative writing according to Phillips: 'What distinguishes the creative writer is that - like the dreamer and the playing child — he has found a way of rendering unacceptable desires into sharable form.' ${ }^{43}$ Referring to the imaginative uncovering of forbidden and denied desires, Freud explains the impact of literary portrayals: 'Like Oedipus, we live in ignorance of the desires that offend morality, the desires that nature has forced upon us, and after their unveiling we may well prefer to avert our gaze from the scenes of our childhood.' ${ }^{44}$ Freud corroborates this argument with a reference to Hamlet, and suggests that Hamlet's hesitation in fulfilling his late father's injunction to avenge his death is due to the repressed realisation that the murderer, his uncle, has in fact achieved what he himself desired, the death of his father and the possession of his mother. This interpretation of the dynamics of childhood and family life subverts the sentimental view of innocence and harmony idealized in the romantic tradition. 'The desires that nature has forced upon us' are complex and ambiguous, but ultimately centre on the desire for love, its

${ }^{39}$ Freud, The Penguin Frend Reader, 476

${ }^{40}$ Freud, The Interpretation of Dreams, 156.

${ }^{41}$ Jonathan Lear, Love and Its Place in Nature (Yale: Yale University Press, 1998), 54.

42 Brendan Kennelly, Brendan, Now (Northumberland: Bloodaxe Books Ltd, 2006), 7.

43 Adam Phillips, Adam, Promises, Promises: Essays on Poetry and Psychoanalysis (New York: Basic Books, 2002), 7.

${ }^{44}$ Freud, The Interpretation of Dreams, 157. 


\section{REALISTIC ROMANTIC}

offering and its reception. Morality, social demands, and the intricacies of human relationships can often frustrate and distort this desire.

In his critique of morality, and of religion as an aspect of that morality, Freud agrees with Nietzsche's thesis that all moral values are pragmatic in nature and that their effect is often the creation of a herdmentality and the diminishment of individual autonomy. Freud urges a rejection of the illusory consolations of religion in favour of a more realistic acknowledgement and appreciation of life as it is: 'Of what use to them is the mirage of wide acres in the moon, whose harvest no one has ever seen? As honest small-holders on this earth they will know how to cultivate their plot in such a way that it supports them.' 45 Freud acknowledges 'the value and importance of religion,' but he argues that 'it has no right in any way to restrict thought'; herein lies the danger of compliance to unquestioned conviction and formulation: 'The prohibition against thought issued by religion to assist in its self-preservation is also far from being free from danger either for the individual or for human society. ${ }^{36}$

Freud reveals, in his depiction of human relations, in mythology, literature, and case histories, as well as in his discussion of his own dreams and experiences, the rivalries, deceptions, envies and jealousies- the love-hate triangles permeating the psychic life of the individual-and he sees the resolution of these conflicts through a tolerance for ambiguity, in contrast to their denial, as the key to optimum living. His reinterpretation of family life acknowledges the competitive nature of the child's environment, and portrays the role of the family as constricting as well as protecting. The child gradually realises that desire is limited and thwarted by the unconsciously understood values and taboos of his community. Certain wishes and dreams are necessarily dismissed and 'forgotten,' but as Freud explains in his description of this 'process of repression, which we must stress is not to be equated with abolition, ${ }^{37}$ the unfulfilled wishes are never completely eradicated, but rather are buried in the unconscious of the ego from where they continue to exert an influence over our lives. Lacan concurs with this interpretation of repression: 'This is what is essential in repression. It's not that the affect is suppressed, it's that it is displaced and unrecognizable. ${ }^{48}$

\section{Repression}

If the meaning of our dreams usually remains obscure to us . . . it is because of the circumstances that at night there also arise in us wishes of which we are ashamed; these we must conceal from ourselves, and they have

\footnotetext{
45 Freud, The Frend Reader, 717.

${ }^{46}$ Ibid., 789.

${ }^{47}$ Sigmund Freud, The Psychology of Love (London: Penguin, 2006), 215.

48 Jacques Lacan, Jacques, The Other Side of Psychoanalysis: The Seminar of Jacques Lacan Book XVII (London: W.W. Norton \& Company, 2007), 144.
} 
consequently been repressed, pushed into the unconscious. ${ }^{49}$

The ideal of self-acceptance remains a mirage of clichéd agreement unless it translates into acknowledgement and ownership of the vast complexity and ambiguity of human being. Disavowal, rejection and denial of selected aspects of the self in pursuit of a more ideal image, and the alternating affirmation and negation, are accomplished through selective amnesia, selfdeception, or the projection of what is disowned onto a convenient other. Through this phenomenon, part of the self is deemed unacceptable and unwelcome; the self is not loved in its full and changing complexity. A corollary to this self-rejection is a simultaneous dismissal of the full possibility of the other. Incomplete versions of self and other, while seemingly convenient and pleasing, restrict the possibility of relationship, including that of love, to experiences which are partial and conditional.

Freud's discovery that unconscious forces permeate and influence our desires, emotions, thoughts and actions, and that often there is an unconscious rejection and disavowal of uncomfortable and unacceptable drives and impulses, led to his formulation of repression as the activity whereby what is feared and unwelcome is kept from consciousness. The reasons for this repression are, in Freud's analysis, to be found in early childhood experiences, when unpalatable realities, portrayed in private thought or public behaviour, in oneself or in one's carers, overwhelmed the subject's ability to assimilate them. According to Freud, these repressed memories had their roots in sexual wishes or fantasies which could not be given expression in the face of adult codes of morality and reality. Thus the authentic experience of the child/adult did not fit the picture of reality which one was expected to embody, survival depended on acceptance of another reality, and these early experiences were denied and split off from consciousness. According to Freudian psychoanalysis, maturity entails coming to terms with these split-off aspects of the self, a withdrawal of projections, and integration of all that one is.

Adam Phillips sees the attempt at unselective self-acceptance as one of the key roles of psychoanalysis: 'Psychoanalysis asks us to reconsider the unacceptable, in ourselves and in others . . . [it] asks what, if any, alternatives there are to scapegoating; and what our lives would be like if there were. ${ }^{50} \mathrm{In}$ this sense, self-acceptance would entail a recognition and acknowledgement of aspects of humanity which are otherwise denied, or at least projected onto some monstrous other; ${ }^{51}$ passion, sexuality, aggression, envy and many other components of human nature which are rejected and denied in the quest for a superior image of who we are. Kearney points to this deception as a

${ }^{49}$ Freud, The Freud Reader, 440.

${ }^{50}$ Phillips, Adam, Side Effects, xiv.

51 The dangers inherent in this projection of evil, aggression, cruelty and terror, and any human characteristics which are deemed uncomfortable or unacceptable, are explored by Richard Kearney in his work Strangers, Gods and Monsters; the title is suggestive of the scapegoats which are constructed to facilitate this projection. 


\section{REALISTIC ROMANTIC}

threatening obstacle to human relations: 'The threat to a genuine relation to others comes in fetishizing the Other as much as it does in glorifying the Ego. ${ }^{52}$ In the absence of acceptance, of self, of others, and of reality, denial and deception are inevitable, and the potential for love, of self and of others, is thwarted.

In his realistic appraisal of the individual's life in society-family, community, culture - and the inevitable constraints that such relational living entails, Freud acknowledged the necessity of some degree of repression as one progresses from the narcissist preoccupation and infantile sense of omniscience of childhood to a more mature awareness of one's place in the interconnectedness of human beings and their relation to the world: 'Just as the planet still circles round its sun, yet at the same time rotates on its own axis, so the individual partakes in the development of humanity while making his own way through life. ${ }^{53}$ As the child moves through a growing awareness of prohibitions and restrictions, expressed through the family and the larger community, it gradually develops a super-ego, an internalisation of the rules and judgements of the authority figures in its life, and the transition from an 'objective fear to a conscience-based fear. ${ }^{54}$ The critical and moralising function of the super-ego develops as external sources of judgement and punishment are internalised: 'As the child was once under a compulsion to obey its parents, so the ego submits to the categorical imperative of its superego. ${ }^{55}$ The super-ego uses guilt, fear, and self-reproach as its primary means of enforcing these internalized rules; it functions as a voice of conscience, repressing the desires of the id, and forcing the ego to inhibit pleasure-seeking impulses in pursuit of morally acceptable goals. It sets up an image of ideals to be worked towards, and it acts as judge and censor in the inevitable conflict between desire and morality. The unavoidable tension between the ego and this prohibiting super-ego can result in profound feelings of melancholy and guilt: 'The Uber-Ich imposes the strictest moral standards on its helpless victim, the $I c h$; indeed it represents the claims of morality as a whole, and we see at a glance that our moral feeling of guilt is the expression of the tension between the Ich and the Uber-Ich. ${ }^{56}$ Depending on the nature of what has been internalised, this super-ego will be compassionate, understanding and realistic, or punitive, unforgiving and idealistic, and most commonly operating on a continuum between the two. The characteristics of this internal authority will dictate the degree and the nature of the repression, while it will also be decisive in determining the influence of cultural and societal values and expectations on the individual. In a healthy developmental maturation the super-ego is internalized with awareness and flexibility, it is recreated in accordance with one's own judgements and ongoing experience. It coincides with re-

${ }^{52}$ Richard Kearney, Strangers, Gods and Monsters: Ideas of Otherness (London: Routledge, 2003), 229.

${ }^{53}$ Freud, Civilization and Its Discontents, 77.

${ }^{54}$ Freud, An Outline of Psychoanalysis, 57.

${ }_{55}^{5}$ Freud, The Frend Reader, 651.

${ }^{56}$ Freud, An Outline of Psychoanalysis, 56. 
interpretation and re-narration in an on-going embrace of experience and knowledge, and in this scenario it becomes a constructive and instructive force in the living of a satisfactory life; it becomes the ego-ideal, which enables the sublimation of one's desires and passions in a way which facilitates a satisfactory compromise between individual satisfaction and the demands of civilization. In other cases however, the super-ego becomes a tormenting, critical and insatiable voice of condemnation and shame resulting in denial and repression.

The repressive role of the internal super-ego is reflected in the power of 'the cultural super-ego. ${ }^{57}$ The analogy between the superego and the superstructure of the state is outlined in Freud's critique of civilization, Civilization and Its Discontents, where he explores the inevitable conflict between the freedom and the drives of the individual and the repression and curtailment imposed by civilized society: 'it is a conflict, then, between what the drive demands and what reality forbids. ${ }^{58}$ According to Gay, in his biography of Freud, 'Freud found the predicament of civilized humanity easy to state: men cannot live without civilization, but they cannot live happily within it . . . at best, sensible human beings may merge a truce between desire and control. ${ }^{59}$ Freud describes civilization as the sum total of those achievements and institutions that distinguish our life from that of our animal ancestors and serve the dual purpose of protecting human beings against nature and regulating their mutual relations. ${ }^{\prime} 00$ The protective and regulating authority of society places the well-being of the community above the instinctual strivings of the individual; therefore, according to Freud, 'individual liberty is not an asset of civilization' ${ }^{61}$ Freud sees that society creates mechanisms to ensure social control of human instincts, and that consequently life in society necessarily frustrates some of our fundamental desires: 'In this way civilization overcomes the dangerous aggressivity of the individual, by weakening him, disarming him and setting up an internal authority to watch over him, like a garrison in a conquered town.' 62 While stressing the incompatibility of civilization and human happiness, Freud does not deny the necessary protective role of regulation and consensus: 'Civilized man has traded in a portion of his chances of happiness for a certain measure of security." ${ }^{63}$ Freud argues that adaptation to social and cultural life necessitates the control of primitive instincts, especially sexuality and aggression: We recognize that it is easy for the barbarian to be healthy, whereas it is a difficult task for the civilized human.'64 Thus, the development of personality is an ongoing accommodation of one's

\footnotetext{
${ }^{57}$ Freud, Civilization and Its Discontents, 79.

${ }^{58}$ Freud, The Penguin Frend Reader, 64.

59 Peter Gay, Freud: A Life for Our Time (London: W.W. Norton \& Company, 1998), 363.

${ }^{60}$ Freud, Civilization and Its Discontents, 27.

${ }^{61}$ Ibid., 32.

${ }^{6}$ Ibid., 61.

${ }^{63}$ Ibid., 51.

${ }^{64}$ Freud, The Penguin Frend Reader, 40,
} 


\section{REALISTIC ROMANTIC}

deepest drives to the demands and laws of social living. This accommodation exacts a toll: 'the restrictions imposed on our drives mean that a serious psychological burden is laid upon us. ${ }^{65}$ Repression, denial, and subjugation characterized Western society in general, according to Freud, and the resulting breakdown and disaster were only too evident in the events of the twentieth century. Linking 'civilized sexual morality and modern nervous illness,' Freud refers to the 'double standards' imposed by society: 'a society that entertains such a double standard cannot carry 'love of truth, honesty, and humanity' beyond a certain narrow limit; it cannot help teaching its members to cloak the truth, to gloss over things, and to deceive themselves and others. ${ }^{66}$ His critique of Western society was particularly directed against American culture, and its obsession with success and money. In a letter to Ernest Jones in 1921, Freud stated that for the Americans 'competition is more pungent with them, not succeeding means civil death to every one, and they have no private resources apart from their profession, no hobby, games, love, or other interests . . . and success means money.' ${ }^{67}$ Thus, in his biography of Freud, Gay notes that 'his earliest comments on Americans had centred on their inability-as he saw itto feel, or express, love' 68 One wonders if these comments are applicable to most Western nations. Indeed, Freud noted, in a letter to Wilhelm Fliess in March 1902, that both Europe and America were in thrall to some rule; 'I have learned that the old world is ruled by authority, as the new is ruled by the dollar.' ${ }^{69}$ This analysis has led some commentators to view Freud's vision as essentially pessimistic. In words which resound with T.S. Eliot's observation, 'human kind / cannot bear very much reality,' ${ }^{70}$ Freud poignantly reflects that 'life, as we find it, is too hard for us; it brings us too many pains, disappointments and impossible tasks. In order to bear it we cannot dispense with palliative measures. ${ }^{71}$ These palliative measures are probably as diverse as human nature itself.

The pessimistic nature of Freud's vision of human nature is central to Philip Rieff's understanding of Freudianism. On a note of resigned disillusionment, he states that 'psychoanalysis is yet another method of learning how to endure the loneliness produced by culture' and he refers to 'the normality of disillusion and a controlling sense of resignation, which was the most for which Freud had hoped. ${ }^{7} 2$ Rieff credits Freud with ripping away the facades of conventional notions of self-understanding, freedom and honesty. He discerns in Freudian anthropology the idea of psychological man as

${ }^{65}$ Freud, The Interpretation of Dreams, 101.

${ }^{66}$ Freud, Civilization and Its Discontents, 86.

${ }^{67}$ Sigmund Freud, quoted. in Gay, Frend: A Life for Our Time, 383.

${ }^{68}$ Gay, Freud: A Life for Our Time, 386.

69 Sigmund Freud, The Complete Letters of Sigmund to Wilhelm Fliess: 1887- 1904, ed. by Jeffrey Masson (London: Harvard University Press, 1985), 457.

70 T.S. Eliot, The Complete Poems \& Plays (London: Faber and Faber Limited, 2004), 172.

${ }^{71}$ Freud, The Freud Reader, 728.

72 Philip Rieff, Freud: The Mind of the Moralist (Chicago: The University of Chicago Press, 1979), 43. 
essentially a contradiction, a creature of not finally satiable instincts, impulses, and desires, in endless tensions with himself or herself and society; he is tragically doomed:

Freud maintains a sober vision of man in the middle, a go-between, aware of the fact the he had little strength of his own, forever mediating between culture and instinct in an effort to gain some room to manoeuvre between these two hostile forces. Maturity, according to Freud, lay in the capacity to keep the negotiations from breaking down. ${ }^{73}$

Certainly, Freud's analysis is that human life is inevitably conflictridden, but in accepting this reality Freud enables us to deal with it; as Lear states, 'For Freud discovered in the heart of these battles at least the potential for human growth. ${ }^{74}$ Martha Nussbaum concurs with this ambiguity as it applies to love: 'We deceive ourselves about love-about who, and how, and when, and whether. We also discover and correct our self-deceptions. ${ }^{75} \mathrm{By}$ acknowledging the reality of conflict in human nature Freud enables the possibility of its accommodation and resolution.

\section{The Art of Living Based on Love}

Our inborn instincts and the world around us being what they are, I could not but regard that love is no less essential for the survival of the human race than such things as technology. ${ }^{76}$

In the practical situation of clinical work, Freud attempted to free his patients from the tyranny of repression, guilt and anxiety. However, the development of his thought led Freud to believe that as well as attempting to ease the pain of those who were mentally distressed, 'psychoanalysis was also the starting-point of a new and deeper science of the mind which would be equally indispensable for the understanding of the normal. ${ }^{77}$ The techniques of psychoanalysis were developed with the aim of bringing to consciousness that which had been repressed; these techniques were, the interpretation of dreams - the uncovering of their latent meaning as distinct from the distortions and displacements of their manifest expression, the rule of 'free

\footnotetext{
${ }^{73}$ Philip Rieff, The Triumph of the Therapentic: Uses of Faith after Frend (Florida: Harcourt, 1966), 31.

${ }^{74}$ Jonathan Lear, Love and Its Place in Nature (Yale: Yale University Press, 1998), 27.

${ }^{75}$ Martha Nussbaum, Love's Knowledge: Essays on Pbilosopby and Literature (New York: Oxford University Press, 1992), 261.

${ }^{76}$ Erik Erikson, The Life Cycle Completed (New York: W.W. Norton \& Company, 1998), 20.

${ }^{77}$ Freud, The Interpretation of Dreams, 30.
} 


\section{REALISTIC ROMANTIC}

association'-the demand for uncensored expression of one's innermost thoughts, 'a withdrawal of the watchers from the gates of the intellect,' 78 and the provision of a non-judgemental, understanding and 'neutral' listener- the unprejudiced attention to the concerns of the individual. Through these techniques, according to Freudian psychoanalysis, repressed wishes are revealed, traumatic events are recalled, and the lingering influence of past experiences is acknowledged. Nietzsche's plea for understanding is answered: 'Listen to the dream which I dreamed, friends, and help me to read its meaning. ${ }^{79}$

At the core of much of the neuroses which presented themselves in the consulting rooms, Freud identified love, its distortions, its loss, its necessity, and the obstacles to its experience, as a central factor, leading him to contemplate 'this recognition of love as one of the foundations of civilization.' ${ }^{80}$ The universal need for love is often not gratified, and Freud suggests that the psychoanalyst attempts to replicate what has been neglected and lacking;

the doctor, in his educative work, makes use of one of the components of love. . . side by side with the exigencies of life, love is the great educator; and it is by the love of those nearest him that the incomplete human being is induced to respect the decrees of necessity and to spare himself the punishment that follows any infringement of them. ${ }^{81}$

The desire for happiness epitomised in the recollected infantile pleasures of being loved, cared for, attended to and responded to, and the unhappiness experienced when these desires are denied and unspoken, form the basis of the analytic encounter. In this practical application of Freud's theories self-knowledge is facilitated by the encounter with another. The relationship between self and other, between analyst and analysand, enables an enlargement of consciousness, as conflicts and neuroses are interpreted and experienced with greater awareness. As Freud stated in a letter to Jung in December 1906, 'Essentially, one might say, the cure is effected by love.' 82 The contemporary psychoanalyst/philosopher, Julia Kristeva, concurs with this understanding as she asks: 'For what is psychoanalysis if not an infinite quest for rebirths through the experience of love?' 83 The absence of love and the obstacles to its experience result in alienation from reality, 'neurotics turn away

78 Ibid. 17.

${ }^{79}$ Friedrich Nietzsche, Thus Spoke Zarathustra (London: Penguin Books, 2003), 156.

${ }^{80}$ Freud, The Frend Reader, 743.

81 Ibid. 591.

82 Sigmund Freud and Carl Jung, The Freud/Jung Letters (Princeton: Princeton University Press1974), 10.

${ }^{83}$ Julia Kristeva, Tales of Love (New York: Columbia University Press, 1987), 2. 
from reality because they find it unbearable — either the whole or parts of it.' ${ }^{94}$ The need to love and to be loved is portrayed in the psychoanalytic setting by the development of 'transference love,' whereby the analysand transfers feelings and wishes onto the analyst which actually belong to an earlier experience and an earlier relationship. As Ricoeur states, 'the therapeutic relation acts as a mirror image in reviving a whole series of situations all of which were already intersubjective. ${ }^{85}$ In this transference relationship, what is 'forgotten' is acted out in a repetition of earlier relationships and responses; 'the compulsion to repeat. . . takes the place of the impulse to remember.'86 The links between memory, forgetfulness and dreams, and the phenomenon of transference, is suggested by Nietzsche: 'What we do in dreams we also do when we are awake; we invent and fabricate the person with whom we associate- and immediately forget that we have done so. ${ }^{97}$

With these techniques of psychoanalysis, Freud ascertains that most adult neuroses or mental suffering originate in childhood experiences, but he also claims that transference is a universal phenomenon in human experience. In exploring these childhood experiences which resulted in 'the tangled roots of adult love. ${ }^{\prime 8}$ Freud developed a theory of sexuality which stated that most problems in living have their source in sexual or 'erotic' experiences. This theory of infantile sexuality was greeted with horror and disgust in Freud's time, and today is still shunned by many. It is argued by some commentators, such as Lear, that Freud's concept of sexuality was broader than its more common connotations, and is closer to our idea of 'sensuality,' sensual life in all its forms. ${ }^{89}$ Freud elaborates on his theory in one of his later essays: 'the sexual impulses are regarded as including all of those merely affectionate and friendly impulses to which usage applies the exceedingly ambiguous word 'love'. ${ }^{90}$ Indeed, Freud describes 'two currents whose union is necessary to ensure a completely normal attitude in love . . . as the affectionate and the sensual current. The affectionate is the older of the two.' ${ }^{91}$ According to Freud's theory, the present predicament of the individual is seen to be determined by the experiences, traumatic or otherwise, of the past; the symptoms of illness are interpreted as the translation of repressed material; and the restoration of psychic harmony and equilibrium is attained through the integration of conflicted and disowned aspects of the self. However, Freud frequently reminds us that the difficulties, in living and in loving, which are observed in the neurotic, are prevalent universally; 'we have since found good reason to suppose that our patients tell us nothing that we might not also hear

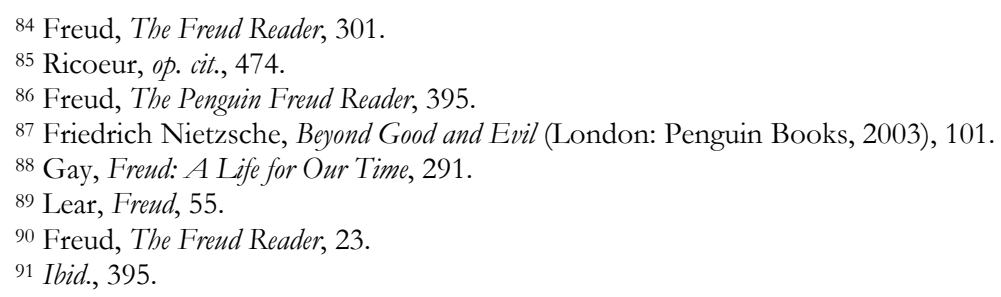




\section{REALISTIC ROMANTIC}

from healthy people, ${ }^{9} 92$ and he postulates that transference is the essential character of every state of being in love' 93 It is the rejection of reality, one's own and that of others, that poses the obstacle to love and happiness, and thus Freud insists that it is only in embracing the conflicting, ambiguous nature of life in its ugliness and beauty, its pain and joy, that one can be free to live and love; 'psychoanalytic treatment is founded on truthfulness. ${ }^{94}$

Lacan refers to this quest for truth as central to Freud's work: 'Freud was taken up in the quest for a truth which engaged him totally, including there in his own self,' and he interprets the scientific domain of this endeavour:

Freud progressed on a course of research which is not characterized by the same style as other scientific research. Its domain is that of the truth of the subject. The quest for truth is not entirely reducible to the objective, and objectifying, quest of ordinary scientific methods. What is at stake is the realization of the truth of the subject. ${ }^{95}$

The difficulties at the heart of love are not proof of its impossibility, but rather the denial of its complexities and ambiguities pose obstacles which are insurmountable while they remained denied; 'we are never so defenceless against suffering as when we love, never so helplessly unhappy as when we have lost our loved object or its love. But this does not dispose of the technique of living based on the value of love as a means to happiness. ${ }^{96}$ Freud lists this technique as one of 'the methods that human beings employ in trying to gain happiness,' and the following outline suggests his admiration for an 'art of living' based on love:

this particular technique in the art of living. . . does not turn away from the external world: on the contrary, it clings to the things of this world and obtains happiness through an emotional attachment to them. Nor is it content with the avoidance of unpleasurable experience, a goal that derives, as it were, from tired resignation; indeed, it bypasses this goal, pays no attention to it, and adheres to the original, passionate striving for the positive achievement of happiness. Perhaps it gets closer to this goal than any other method. I am referring of course to the way of life that places love at the centre of everything

${ }^{92}$ Ibid., 439

${ }^{93}$ Ibid., 385.

${ }^{94}$ Ibid., 382

${ }^{95}$ Jacques Lacan, The Seminar of Jacques Lacan: Book 1: Freud's Papers on Tecbnique 1953 1954 (London: W.W. Norton \& Company, 1991), 20, 21.

${ }^{96}$ Freud, The Frend Reader, 733. 


\section{K. O'DWYER 113}

and expects all satisfaction to come from loving and being loved. ${ }^{97}$

The insights of Freud into the workings of the human mind demand a renunciation of unrealistic portrayals of human nature, an acceptance of vulnerability and fallibility, and a rejection of mirages of omniscience and invincibility; they propose a realistic awareness and acceptance of one's limitations in order to grapple with the vicissitudes of life as it is, and they urge a confrontation with the obstacles to love and happiness as the only route to overcoming them. Freud's writings, academic and personal, assert that the concepts of 'human' and 'perfection' are incompatible. For him this is an inescapable truth of the human condition. However, the imperfectability of the human being is not an insurmountable obstacle to love and happiness, but rather an integral and often enriching component of their experience.

Freud's thought explores and permeates areas of human being previously uncharted; his insights into human nature are the culmination of his self-observation as well as his clinical work, his attempts to understand the motivations, needs and potentialities of the human subject, and his ongoing openness to revision and re-interpretation. Freud was passionate about the subject of his life's work, and this passion accommodated the possibility of correction: 'a person in love is humble. ${ }^{98}$ His view of the human condition dispels with untenable glorifications and super-human depictions; but in embracing the reality of the human subject as imperfect, ambivalent, and not fully knowable to self or to others, Freud remains convinced of the power of love to answer many human needs, and to enhance the experience of human living: 'but he would have us remember most of all / to be enthusiastic over the night, / not only for the sense of wonder / it alone has to offer, but also / because it needs our love. ${ }^{99}$

Department of English Language, University of Limerick, Ireland

\section{References}

Auden, W.H., Collected Poems (London: Faber and Faber 1994).

Boothby, Richard, Freud as Philosopher (New York: Routledge, 2001).

Buber, Martin, Between Man and Man (New York: Routledge Classics, 2004).

Eliot, T.S., The Complete Poems \& Plays (London: Faber and Faber Limited, 2004).

Freud, Sigmund and Carl Jung, The Freud/Jung Letters (Princeton: Princeton University Press, 1974).

Freud, Sigmund, An Outline of Psychoanalysis (London: Penguin Classics, 2003).

\footnotetext{
${ }^{97}$ Freud, Civilization and Its Discontents, 19.

${ }^{98}$ Freud, The Frend Reader, 560.

99 Auden, Collected Poems, 276.
} 


\section{REALISTIC ROMANTIC}

Civilization and Its Discontents, trans. by David McLintock

(London: Penguin Classics, 2002).

, Introductory Lectures on Psychoanalysis, trans. by James Strachey

(London: Penguin Books, 1991).

, The Complete Letters of Sigmund to Wilhelm Fliess: 1887- 1904, ed. by

Jeffrey Masson (London: Harvard University Press,1985).

, The Freud Reader, ed. by Peter Gay (New York: W.W. Norton \& Company, 1995).

, The Interpretation of Dreams, trans. by A. A. Brill (Herfordshire: Wordsworth Editions Limited, 1997).

The Penguin Freud Reader, ed. by Adam Phillips (London: Penguin, 2006).

The Psychology of Love (London: Penguin, 2006).

Gay, Peter, Freud: A Life for Our Time (London: W.W. Norton \& Company, 1998).

Jacques Lacan, The Seminar of Jacques Lacan: Book 1: Freud's Papers on Technique 1953-1954 (London: W.W. Norton \& Company, 1991), 20, 21.

Kaufmann, Walter, Discovering the Mind, Volume III: Freud Versus Adler and Jung (New York: McGraw-Hill, 1980).

Kearney, Richard, Strangers, Gods and Monsters: Ideas of Otherness (London: Routledge, 2003).

Kennelly, Brendan, Now (Northumberland: Bloodaxe Books Ltd, 2006).

Kristeva, Julia, Tales of Love (New York: Columbia University Press, 1987)

Lacan, Jacques, Ecrits: A Selection, trans. by Bruce Fink (London: W.W. Norton \& Company, 2004).

, The Other Side of Psychoanalysis: The Seminar of Jacques Lacan Book XVII (London: W.W. Norton \& Company, 2007).

Lear, Jonathan, Freud (New York: Routledge, 2005). , Love and Its Place in Nature (Yale: Yale University Press, 1998).

Nietzsche, Friedrich, Beyond Good and Evil (London: Penguin Books, 2003). , Thus Spoke Zarathustra (London: Penguin Books, 2003).

Nussbaum, Martha, Love's Knowledge: Essays on Philosophy and Literature (New York: Oxford University Press, 1992).

Phillips, Adam, Equals (New York: Basic Books, 2002). Promises, Promises: Essays on Poetry and Psychoanalysis (New York:

Basic Books, 2002). Side Effects (London: Penguin Books, 2006).

Ricoeur, Paul, Frend and Philosophy (New Haven: Yale University Press, 1970).

Rieff, Philip, Frend: The Mind of the Moralist (Chicago: The University of Chicago Press, 1979). , The Triumph of the Therapentic: Uses of Faith after Frend (Florida: Harcourt, 1966).

Sartre, Jean-Paul, Being and Nothingness (Washington: Washington Square Press, 1992).

Nausea (New York: New Directions Publishing Corporation, 1969). 
K. O'DWYER 115

The Reprieve (New York: Vintage, 1992).

Webster, Richard, Freud (London: Weidenfeld \& Nicolson, 2003).

Žižek, Slavoj, The Neighbour (London: University of Chicago Press, 2005). 